\title{
Concentration of Total Mercury in the Blood, Urine and Hair of Gold Panners, Gold Traders, People Living in and Around Gold Panning Sites in the Territory of Fizi, DRC
}

\author{
Nsambu Mukondwa Pascal ${ }^{1,2,3, ~ *, ~ M u s i b o n o ~ E y u l ' A n k i ~ D i e u d o n n e ́ ~}{ }^{1}$, Mputu Kanyinda Jean-Noël ${ }^{1}$ \\ ${ }^{1}$ Department of Environmental Sciences, Faculty of Sciences, Doctoral Cycle, University of Kinshasa, Kinshasa, Democratic Republic of \\ Congo \\ ${ }^{2}$ Faculty of Agricultural Sciences and Environment, Evangelical University in Africa, Bukavu, D R of Congo \\ ${ }^{3}$ General Agronomy section, High Institute of Agronomic and Veterinary Studies of Mushweshwe, Bukavu, Democratic Republic of Congo
}

\section{Email address:}

nsambumukonduasumu@gmail.com (N. M. Pascal), musibon.ergs@gmail.com (M. E. Dieudonné),

kanyinda2004@gmail.com (M. K. Jean-Noël)

${ }^{*}$ Corresponding author

\section{To cite this article:}

Nsambu Mukondwa Pascal, Musibono Eyul'Anki Dieudonné, Mputu Kanyinda Jean-Noël. Concentration of Total Mercury in the Blood, Urine and Hair of Gold Panners, Gold Traders, People Living in and Around Gold Panning Sites in the Territory of Fizi, DRC. International Journal of Ecotoxicology and Ecobiology. Vol. 5, No. 1, 2020, pp. 1-12. doi: 10.11648/j.ijee.20200501.11

Received: December 28, 2019; Accepted: January 7, 2020; Published: January 16, 2020

\begin{abstract}
This study covered a demographic sample of 384 people including gold panners, gold traders, people living in and around the gold panning sites in the Fizi territory who were selected from the total population of 17900 people using the stratified sampling technique. The main objective of this study was to determine total mercury content in samples of biological matrixes (blood, urine and hair) provided by the above-mentioned individuals over a 16-month cycle (August and December 2016 to August and December 2017). Total mercury was determined by atomic absorption spectrophotometry (AAS) for each biological matrix studied. The results found revealed that only people residing in the reference site or non-mining site (Lulimba) had the lowest total mercury levels in compliance with WHO standards for all biological matrix studied (blood, hair and urine). In fact, for these entire biological matrixes, gold panners presented the highest total mercury levels, followed in turn by gold traders, subjects living near gold-mercury ( $\mathrm{Au}-\mathrm{Hg}$ ) amalgamation incineration sites and gold trading houses, and villagers living in the gold panning sites. In view of the above, it is necessary to consider adequate solutions that can protect people from mercurial toxicity. To this end, particular attention would be focused on the scrupulous application of safety standards in relation to the handling of mercury in general and other toxic products in particular, the conduct to be followed during the incineration of gold-mercury amalgam, etc.
\end{abstract}

Keywords: Gold Panners, Gold Traders, Fizi Territory, Blood, Urine, Hair, Gold Panning Sites, Eastern Democratic Republic of Cong

\section{Introduction}

Over the last few decades, gold panning has beaten the record in all gold sites in developing countries in Asia (China, India, Mongolia, Korea, Indonesia, Philippines) [1], Latin America (Bolivia, Amazonia) [2] and Africa (Senegal, Ghana, Burkina Faso, Nigeria, Mali, Tanzania, etc.) [3]. Through this form of gold mining; merchant gold is extracted from its ore and concentrated through both traditional and manual methods and processes using several reagents [4].
Gold panning generally uses mercury to extract gold from the ore through the formation of the "gold-mercury" amalgam. This amalgam is then heated to separate the gold from the mercury by evaporation [5]. During these processes, mercury is usually absorbed into the body through several routes such as skin contact, inhalation of its vapors, etc. [6]. However, it is important to note that it is not only gold miners who are exposed to mercury, but also communities living in the vicinity of gold mining sites, especially since the air has no borders. Once absorbed, mercury can be distributed 
throughout the body, but is preferentially found in the kidneys, liver, lungs, red blood cells and brain [6]. Mercury generally undergoes a redox cycle within the organs where it is located. Its half-life in the body varies depending on its form and where it is found. The average half-life of inorganic mercury is 42 days, but if this form is present in the brain, it can remain there for a very long time. Methylmercury has an average half-life of 48 days in the blood and is excreted somewhat more slowly in the rest of the body. Excretion of organic mercury is mainly via the feces, while excretion of metallic and inorganic mercury occurs via the urine or feces [7]. The toxic manifestations of mercury vary according to its nature. In fact, chronic exposure to metallic mercury in vapors form mainly causes symptoms in the central nervous system such as tremors or depressed mood, but can also lead to proteinuria in the kidneys, digestive disorders, vomiting, excessive salivation, uremia, etc. [8]. It can also cause an enlarged thyroid gland and gingivitis. As for inorganic mercury, its target organ is the kidney, where it can induce nephritis, which is an inflammation of the kidney. Organic mercury, essentially methylmercury, targets the central nervous system where it can cause paresthesia (tingling, numbness, etc.), ataxia (lack of coordination of voluntary movements) or neurasthenia (general feeling of fatigue and depression). It can also cause toxic effects such as damage to nerve centers, birth defects, long-term cancer incidence, etc. [9]. Strict adherence to the standards required for handling mercury preserves the health of those who use this toxic product and those who live in the vicinity of the places where it is used [6]. Curiously, gold panners and gold traders in the Fizi territory seem to be unaware of the safe standards for handling dangerous chemicals such as mercury. Wearing protective gloves during amalgamation remains the least of their concerns. On gold panning sites, gold-mercury amalgamation is incinerated in the open air and without a protective mask, ignoring the fact that this process undoubtedly generates mercury in the form of vapors whose content at the gold panning site can reach very worrisome values and even exceed the threshold limit of $1.0 \mu \mathrm{g} . \mathrm{m}^{-3}$ for the exposure of the general population [10]. In view of the above, it appears that gold panners, gold traders and the populations living near the gold panning sites in the Fizi territory would be exposed to toxicological risks from mercury without any concern. Thus, given that to date there is no information on the level of mercury exposure of gold panners, gold traders and individuals living in and around the Fizi gold panning sites, this study specifically seeks to determine the concentrations of total mercury in the urine, hair and blood of the aforementioned individuals as a function of the sites and the Study Campaigns respectively.

\section{Material and Methods}

\subsection{Study Area}

Blood, hair and urine samples were taken in hospitals, medical centers and polyclinics in artisanal gold mining sites in the Fizi territory. This territory is one of the eight territories that make up the province of South Kivu, which is located in the east of the Democratic Republic of Congo. Geographically, the territory of Fizi is located between $3^{\circ} 30^{\prime}$ and 4'51'32" South latitude, 27 ${ }^{\circ} 45^{\prime}$ and $29^{\circ} 14^{\prime} 10^{\prime \prime}$ East longitude. It is bounded to the north by the territory of Uvira, to the west by the territory of Mwenga and Shabunda, to the south by the territory of Kalemie (Tanganyika), and to the east by Lake Tanganyika [11]. Information on the location of different points of blood, urine and hair sampling within the health facilities in Fizi territory is presented in Figure 1.

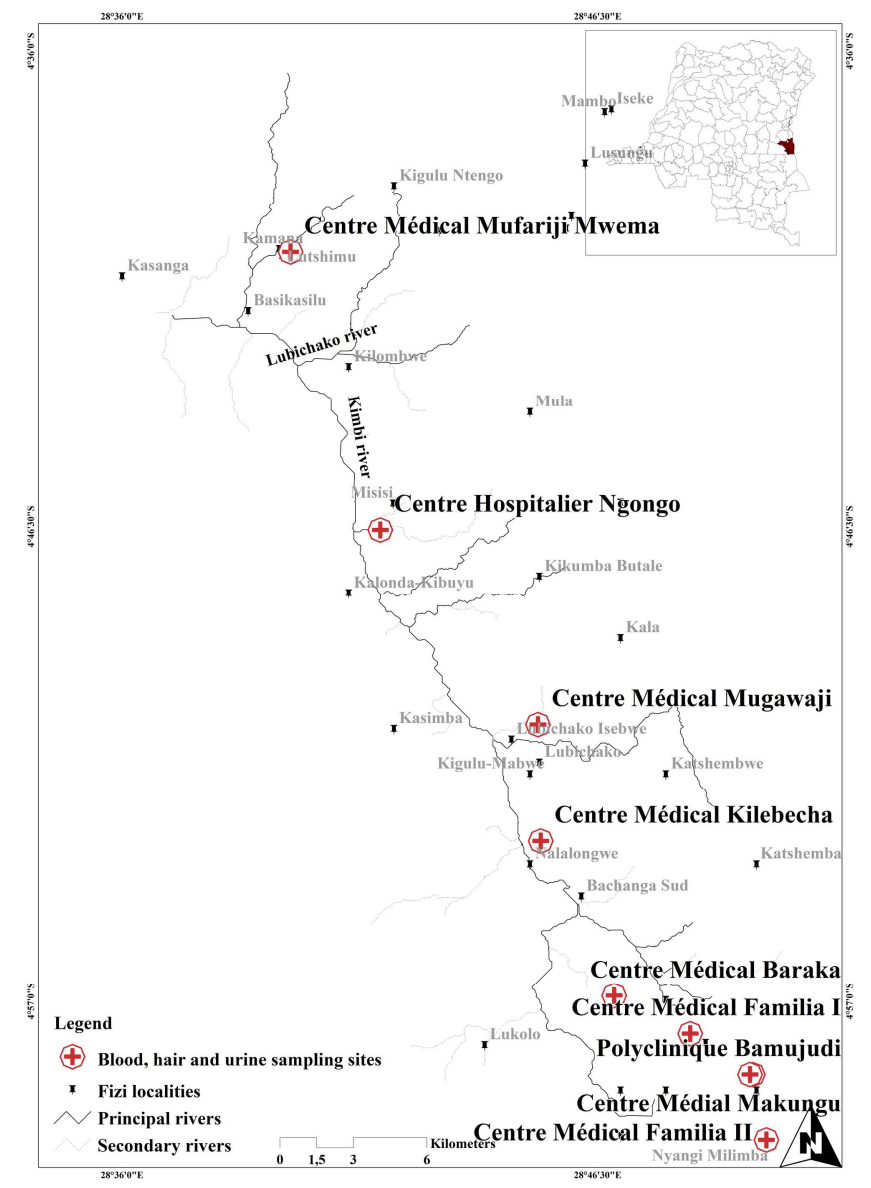

Figure 1. Map of blood, urine and hair samples collection sites in the Fizi Territory.

\subsection{Methods of Sampling and Analysis of fish Samples}

The stratified demographic sample of 384 people was drawn from the population that was 17,900 in size. These people live in Lulimba (reference or non-mining site) and in the gold panning sites of Misisi, Lubichako I, Lubichako II, Tulonge, Ngalula, Kuwa, Makungu and Nyangé, respectively. This stratified sample was extracted from the above-mentioned population using the following formula:

$$
n=\frac{Z_{\alpha}^{2} 2^{x P x Q}}{d^{2}}[12]
$$

Where: 
$Z_{\alpha / 2}^{2}=$ The square of the critical value for the standard normal distribution. This critical value is equivalent to 1.96 for the $95 \%$ confidence level.

$\mathrm{d}=$ Margin of error, in this case it is of the order of $5 \%$.

$\mathrm{P}=$ Proportion of people with the desired characteristics.

$\mathrm{Q}=$ Proportion of people who do not have the desired characteristics.

$$
\mathrm{P}+\mathrm{Q}=1 ; \mathrm{Q}=1-\mathrm{P}
$$

As we had no reference information on the $\mathrm{P}$ value in the gold panning sites of Fizi, i.e. the proportion of individuals from artisanal gold mining sites in Fizi territory with the desired characteristics, i.e. those likely to exceed the WHO threshold for body burden of mercury, we considered the $\mathrm{P}$ value to be $50 \%$ [13]. Thus, if $\mathrm{P}=50 \%=0.5$ then $\mathrm{Q}=1-0.5$ $=0.5$ and replacing each variable of the previous expression of $\mathrm{n}$, we find that the sample size is about 384 persons.

Having determined the above-mentioned sample size, the next step was to adopt the sampling technique that could facilitate the judicious selection of the persons making up the desired sample. To this end, the calculation of the number of individuals that make up the sample and the sampling of the units that make up the sample were carried out using the stratified sampling technique [12]. In fact, stratified sampling consists in choosing $\mathrm{n}$ statistical units (384 for this case) among $\mathrm{N}$ units of a population (17900 subjects for this case) listed in the following procedure:

1) The population is subdivided into relatively homogeneous strata or subgroups. For the present study, each area is a stratum from which individuals will be sought, taking into account the percentages that each stratum occupies in the population.

2) Within each stratum, individuals are selected at random. The grouping of these individuals constitutes the desired stratified sample.

The criteria for exclusions from the demographic sample were as follows:

1) Any individual residing for less than six months in the study areas;

2) Any person who has been residing in the study areas for at least six months and who refused either the questionnaire or the hair, blood and urine sample, or both;

3) Anyone living for at least six months in the study areas who had dental amalgam fillings placed;

4) Anyone who has been living for at least six months in the study setting using lightening soaps and creams;

5) Any individual living for at least six months in the study areas who consumes alcohol, smokes tobacco, or consumes alcohol and smokes tobacco at the same time.

The blood, urine and hair samples studied were taken from the same people making up the stratified demographic sample during 4 campaigns (August 2016, December 2016, August 2017 and December 2017). The blood samples were taken by the laboratory technicians of the hospitals in the Fizi health zone using techniques that comply with the following standard blood sampling standards: proceed with a venipuncture and take $8 \mathrm{~mL}$ of blood aseptically using a metal needle and a $10 \mathrm{~mL}$ syringe; place the blood taken in an EDTA tube previously coded according to the sex and age of the donor of the said blood; stopper this tube containing whole blood and then gently homogenize its contents by turning the said tube upside down. These blood samples were stored in the field at $+4^{\circ} \mathrm{C}$ in a cooler before being sent to the laboratory for ad hoc analysis [14]. The urine samples were collected by the people who participated in this research by strictly following the following steps of the urine collection techniques: throw away the first morning's urine (first urination), start the collection from the second urination onwards, collect all subsequent urinations up to and including the first morning's urine, store the previously labelled bottles containing the 24-hour urine in a cool, dark place. Efficient field storage of the said samples at $+4^{\circ} \mathrm{C}$ was ensured by adding 5 drops of $1 \% \mathrm{HNO}_{3}$ to all contents of the polyethylene vials in accordance with the recommendations of [15].

We took the hair samples by following the following steps of the hair sample collection techniques: Place and roll a shoelace one $\mathrm{cm}$ from the scalp to form a tuft of hair. Cut this tuft flush with the scalp with sterile scissors. Finally, the two pieces of wire holding the tuft of hair were taped to the sampling sheet, which contained all the information necessary to manage the sample: name of the sampling site, date of sampling, sex, age, occupation, the number of the sheet assigned to the sample, etc. The sample was then taken from the site, and the two pieces of wire were placed on the sheet. All this information was inserted in an envelope and kept at room temperature before being sent to the laboratory for appropriate analysis [16].

For all samples of the above-mentioned biological matrices, the total mercury content was determined using atomic absorption spectrophotometry (AAS). In general, this method is based on the two-step analysis principle. For hair samples, the first step is to digest $10 \mathrm{mg}$ of hair samples previously washed with distilled water and dehydrated with acetone. However, for blood and urine samples, the first step is to digest $2 \mathrm{~mL}$ of blood or urine samples that have been properly homogenized in advance.

This digestion is carried out in the presence of acids (pure nitric acid concentrated at $65 \%$, pure sulfuric acid concentrated at $98 \%$, pure hydrochloric acid concentrated at $37 \%$ and hydroxylamine hydrochloride concentrated at $20 \%$ ) and potassium permanganate $\left(\mathrm{KMnO}_{4}\right)$ concentrated at $6 \%$. This step breaks down the organic matter and transforms the mercury into the $\mathrm{Hg}^{2+}$ form. Hydrochloric acid promotes the rapid decomposition of cinnabar $(\mathrm{HgS})$, resistant to the attack of nitric acid and sulfuric acid.

Potassium permanganate ensures complete oxidation of organic compounds refractory to acid decomposition. During this step, the manganese is reduced from the $\mathrm{Mn}^{7+}$ form to the $\mathrm{Mn}^{4+}$ form.

After digestion, a solution of hydroxylamine chloride $\left(\mathrm{NH}_{2} \mathrm{OH} . \mathrm{HCl}\right)$ reduces $\mathrm{MnO}_{2}$ and excess $\mathrm{KMnO}_{4}$ without 
reducing $\mathrm{Hg}^{2+}$.

During the second step, mercuric ions are reduced to elemental mercury by a solution of stannous chloride $\left(\mathrm{SnCl}_{2}\right)$ concentrated at $10 \%$ are brought into a gas in a cell by bubbling air.

The mercury contained in the cell is assayed by the Atomic Absorption Spectrophotometer (AA500) at the wavelength of $253.7 \mathrm{~nm}$.

The total mercury (THg) concentration in this solution is deduced from the equation of the mercury calibration line.

This calibration line consists of 6 standard points: standard 1 with a concentration of $0.1 \mu \mathrm{g} . \mathrm{L}^{-1}$; standard 2 of concentration $0.5 \mu \mathrm{g} . \mathrm{L}^{-1}$; standard 3 of concentration $1 \mu \mathrm{g} . \mathrm{L}^{-1}$; standard 4 of concentration $2 \mu \mathrm{g} . \mathrm{L}^{-1}$; standard 5 with a concentration of $4 \mu \mathrm{g} . \mathrm{L}^{-1}$ and standard 6 with a concentration of $5 \mu \mathrm{g} . \mathrm{L}^{-1}$.

The total mercury content in different hair samples is determined using the following relationship:

$$
T H g\left(\frac{\mu g}{g}\right)=\frac{[(\text { AbsEch }- \text { AbsB })-b]}{\text { a.PE. } 0,001} \mathrm{xFd}
$$

Where THg: Total mercury content in the hair sample $\left(\mu \mathrm{g} . \mathrm{g}^{-1}\right)$; AbsEch: absorbance of the hair sample; AbsB: absorbance of the blank solution (control solution); a: slope $(\mathrm{Y}=\mathrm{aX}+\mathrm{b})$; b: intercept; Fd: dilution factor, if necessary; PE: test sample in milligram. Note: in order to validate the analysis, it must be ensured that the calibration line has a correlation coefficient with a square $r^{2}$ greater than or equal to 0.98 [7].

The concentration of total mercury (THg) in blood and urine samples is calculated from the regression equation for the analyte (i.e., mercury) obtained from the calibration line or curve. In addition, the concentration of total mercury
(THg) in blood and urine samples is calculated from the regression equation for the analyte (i.e., mercury) obtained from the calibration line or curve. This one is identical to the hair samples. The concentration of total mercury in urine and blood samples is determined by the expression below:

$$
T H g\left(\frac{\mu g}{L}\right)=\frac{[(\text { AbsEch }-\mathrm{AbsB})-b]}{\mathrm{a} . \mathrm{PE}} \mathrm{xFd}
$$

Where THg: Total mercury in the blood or urine sample ( $\mu$ g.L-1); AbsEch: Absorbance of the blood or urine sample; AbsB: Absorbance of the blank solution (control solution); a: Slope $(Y=a X+b)$; $b$ : Intercept; Fd: Dilution factor, if necessary; PE: Test sample in milliliters. Note: in order to validate the analysis, it is necessary to ensure that the calibration line has a correlation coefficient whose square $\mathrm{r}^{2}$ is greater than or equal to 0.98 [7].

\subsection{Statistical Treatment of Data}

The data was encoded and processed using Microsoft Excel 2010. R version 2.15.1 software was used for descriptive data analysis while XLSTAT 2016 was used to separate the means of different factors at the level of significance of $5 \%$.

\section{Results and Discussion}

\subsection{Total Mercury Levels in Blood According to the Sites and Campaigns Studied}

The results for total mercury levels in blood according to the sites and campaigns studied are presented in Table 1.

Table 1. Concentrations of total mercury (THg) in blood according to the sites and campaigns studied.

\begin{tabular}{llll}
\hline \multirow{2}{*}{ THg $\left(\boldsymbol{\mu g . \mathbf { L } ^ { - 1 } )}\right.$} & \multicolumn{1}{l}{ Etó } & \multicolumn{1}{l}{ Kacumvi } & Kimbi \\
\cline { 2 - 3 } & P-value for the Campaigns: $\mathbf{0 . 0 0 0}$ & $44.878 \pm 1.214$ \\
\hline Campaign 1 & $47.341 \pm 1.114$ & $48.300 \pm 3.350$ & $61.398 \pm 1.306$ \\
Campaign 2 & $52.697 \pm 1.120$ & $80.315 \pm 3.369$ & $56.463 \pm 1.316$ \\
Campaign 3 & $57.654 \pm 1.128$ & $72.177 \pm 3.456$ & $64.929 \pm 0.786$ \\
Campaign 4 & $63.726 \pm 1.259$ & $81.151 \pm 3.527$ & $1.248 \pm 0.869$ \\
Mean & $55.354 \pm 1.155 e$ & $70.690 \pm 3.426 d$ & $56.679 \pm 1.291 e$ \\
\hline
\end{tabular}

\begin{tabular}{|c|c|c|c|c|c|c|}
\hline \multirow{2}{*}{ THg $\left(\mu \mathrm{g} . \mathrm{L}^{-1}\right)$} & Kuwa & Lubichako & Makungu & Mandje & Misisi & Mean \\
\hline & \multicolumn{6}{|c|}{ P-value for the Rivers: 0.000} \\
\hline Campaign 1 & $53.025 \pm 4.574$ & $72.135 \pm 2.736$ & $37.797 \pm 2.110$ & $83.063 \pm 3.574$ & $34.627 \pm 1.219$ & $46.899 \pm 2.297 \mathrm{c}$ \\
\hline Campaign 2 & $112.663 \pm 4.698$ & $79.318 \pm 2.745$ & $44.446 \pm 2.116$ & $93.910 \pm 3.587$ & $37.885 \pm 1.296$ & $62.653 \pm 2.345 b$ \\
\hline Campaign 3 & $118.653 \pm 4.759$ & $85.578 \pm 2.765$ & $53.517 \pm 2.216$ & $96.016 \pm 3.658$ & $42.823 \pm 1.312$ & $64.882 \pm 2.389 \mathrm{~b}$ \\
\hline Campaign 4 & $133.839 \pm 4.877$ & $99.143 \pm 2.785$ & $59.315 \pm 2.236$ & $107.755 \pm 3.696$ & $48.718 \pm 1.320$ & $73.294 \pm 2.443 a$ \\
\hline Mean & $104.439 \pm 4.727 a$ & $84.135 \pm 2.756 c$ & $48.769 \pm 2.170 e f$ & $95.222 \pm 3.629 b$ & $41.071 \pm 1.287 f$ & $61.932 \pm 2.368$ \\
\hline
\end{tabular}

Table 1. Continued.

Averages with the same letters on the line or column are not statistically different at the significance level alpha =0.05; Campaign 1: August 2016; Campaign 2: December 2016; Campaign 3: August 2017; Campaign 4: December 2017; THg: Total mercury content.

The results presented in Table 1 revealed that the average values of total mercury concentrations in the blood of all individuals living within and outside the gold panning areas of the Fizi territory were of the order of $61.932 \pm 2.368 \mu \mathrm{g} . \mathrm{L}^{-1}$. By the way, these values of total mercury levels in the blood of the subjects in question varied in a highly significant way from one site to another $(\mathrm{P}$-value $=0.000)$.

In particular, at the non-mining site of Lulimba (reference site), the bloods of individuals showed average total mercury concentrations of the order of $1.220 \pm 0.871 \mu \mathrm{g} . \mathrm{L}^{-1}$ which are 
the lowest and conform to World Health Organization (WHO) standards, stipulating that the acceptable thresholds for total mercury levels in blood are of the order of $8 \mu \mathrm{g} . \mathrm{L}^{-1}$ for unexposed subjects and $15 \mu \mathrm{g} . \mathrm{L}^{-1}$ for exposed subjects.

In addition, the blood total mercury levels of people living within the Fizi artisanal gold mining sites have significantly exceeded WHO standards for blood total mercury levels in exposed individuals.

Thus, the bloods of people living in the Misisi gold panning site had the highest average concentration of total mercury compared to the bloods of individuals living in other gold panning sites $\left(104.439 \pm 4.727 \mu \mathrm{g} . \mathrm{L}^{-1}\right)$, followed in turn by the bloods of people living in the Nyangé gold panning sites (95.222 $\left.\pm 3.629 \mu \mathrm{g} . \mathrm{L}^{-1}\right) ; \quad$ Makungu $\left(84.135 \pm 2.756 \mu \mathrm{g} . \mathrm{L}^{-1}\right)$; Lubichako I $\left(70.690 \pm 3.426 \mu \mathrm{g} . \mathrm{L}^{-1}\right)$; then Lubichako II $\left(56.679 \pm 1.291 \mu \mathrm{g} . \mathrm{L}^{-1}\right)$ and Kuwa $\left(55.354 \pm 1.155 \mu \mathrm{g} . \mathrm{L}^{-1}\right)$ with statistically similar mean total mercury concentrations; Ngalula (48.769 $\left.\pm 2.170 \mu \mathrm{g} . \mathrm{L}^{-1}\right)$; and Tulonge (41.071 $\left.\pm 1.287 \mu \mathrm{g} . \mathrm{L}^{-1}\right)$.

The total mercury concentrations in the blood of subjects living within all the sites studied also varied in a highly significant way from one investigation campaign to another (P-value $=0.000)$ while increasing considerably from Campaign 1 (August 2016) to Campaign 4 (December 2017).

Indeed, Campaign 4 (December 2017) presented the highest values of average total mercury concentrations in human blood for all the above-mentioned study sites $\left(73.294 \pm 2.443 \mu \mathrm{g} . \mathrm{L}^{-1}\right)$ followed respectively by Campaign 3 (August 2017) for which the average total mercury concentrations in blood are of the order of $64.882 \pm 2.389 \mu \mathrm{g} . \mathrm{L}^{-1}$ and Campaign 2 (December 2016) (62.653 $\left.\pm 2.345 \mu \mathrm{g} . \mathrm{L}^{-1}\right)$ for which the average concentrations of total mercury in the blood are statistically equal; finally Campaign 1 (August 2016) for which the average concentrations of total mercury in the blood were of the order of $46.899 \pm 2.297 \mu \mathrm{g} . \mathrm{L}^{-1}$.

These results are similar to those of other researchers who report that the total blood mercury concentrations of individuals living outside the gold mining sites in the Brazilian Amazon and Gyeongsangbuk-do, Korea, were very low and within health standards compared to those of individuals residing in the above gold mining sites whose total blood mercury concentrations greatly exceeded the health standards for total blood mercury concentrations in exposed individuals.

In addition, these researchers also found that total blood mercury levels varied very significantly between study sites and Campaigns [17-19].

\subsection{Total Mercury Levels in Hair According to the Sites and Campaigns Studied}

The results for total mercury levels in hair according to the sites and campaigns studied are shown in Table 2.

Table 2. Concentrations of total mercury (THg) in hair according to the sites and Campaigns studied.

\begin{tabular}{llcc}
\hline Sites / Campaigns and Parameter & Etó & Kacumvi & Kimbi \\
\hline THg $\left(\boldsymbol{\mu g . \mathbf { g } ^ { - 1 } )}\right.$ & P-value for the Campaigns: $\mathbf{0 . 0 0 1}$ & \\
\hline Campaign 1 & $163.425 \pm 2.127$ & $155.735 \pm 1.011$ & $169.121 \pm 2.452$ \\
Campaign 2 & $185.341 \pm 2.254$ & $226.293 \pm 1.096$ & $184.415 \pm 2.563$ \\
Campaign 3 & $171.846 \pm 2.320$ & $274.012 \pm 1.112$ & $158.173 \pm 2.631$ \\
Campaign 4 & $174.633 \pm 2.326$ & $219.655 \pm 2.326$ & $176.142 \pm 2.961$ \\
Mean & $170.539 \pm 2.257 c d$ & $218.924 \pm 1.386 c$ & $0.039 \pm 0.006$ \\
\end{tabular}

Table 2. Continued.

\begin{tabular}{|c|c|c|c|c|c|}
\hline Sites / Campaigns and Parameter & Kuwa & Makungu & Mandje & Misisi & Mean \\
\hline THg $\left(\mu{\left.\mathrm{g} . \mathrm{g}^{-1}\right)}^{-1}\right.$ & \multicolumn{5}{|c|}{ P-value for the Rivers: 0.000} \\
\hline Campaign 1 & $277.526 \pm 2.123$ & $129.066 \pm 1.870$ & $179.322 \pm 2.118$ & $134.248 \pm 1.652$ & $161.668 \pm 1.631 \mathrm{~b}$ \\
\hline Campaign 2 & $269.565 \pm 7.450$ & $157.365 \pm 1.873$ & $306.207 \pm 3.128$ & $149.090 \pm 1.745$ & $195.606 \pm 2.470 \mathrm{a}$ \\
\hline Campaign 3 & $351.577 \pm 8.325$ & $144.545 \pm 1.953$ & $295.903 \pm 3.148$ & $126.374 \pm 1.870$ & $197.166 \pm 2.667 \mathrm{a}$ \\
\hline Campaign 4 & $354.646 \pm 10.369$ & $152.611 \pm 1.963$ & $358.358 \pm 3.158$ & $143.036 \pm 1.875$ & $204.979 \pm 3.729 a$ \\
\hline Mean & $309.498 \pm 7.067 a$ & $145.897 \pm 1.915 d$ & $288.778 \pm 2.888 a b$ & $138.187 \pm 1.786 d$ & $189.855 \pm 2.624$ \\
\hline
\end{tabular}

Averages with the same letters on the line or column are not statistically different at the significance level alpha =0.05; Campaign 1: August 2016; Campaign 2: December 2016; Campaign 3: August 2017; Campaign 4: December 2017; THg: Total mercury content.

The results contained in Table 2 show that the mean values of total mercury concentrations in the hair of all individuals living in the non-mining site of Lulimba (reference site) and within the artisanal gold mining sites in the territory of Fizi (Lubichako I, Tulonge, Lubichako II, Misisi, Kuwa, Ngalula, Nyangé and Makungu) were equal to $189.855 \pm 2.624 \mu \mathrm{g} . \mathrm{g}^{-1}$.

Indeed, these values of total mercury concentrations in the hair of the above-mentioned individuals varied highly significantly from one site to another $(\mathrm{P}$-value $=0.000)$. In particular, at the non-mining site of Lulimba, the hair of the subjects who participated in the study had average total mercury concentrations equivalent to $0.504 \pm 0.013 \mu \mathrm{g} . \mathrm{g}^{-1}$, which are the lowest and comply with World Health Organization (WHO) standards, which stipulate that the acceptable thresholds for total mercury levels in hair are of the order of $2 \mu \mathrm{g} . \mathrm{g}^{-1}$ for unexposed subjects and $1 \mu \mathrm{g} . \mathrm{g}^{-1}$ for exposed subjects. However, the levels of total mercury in the hair of individuals living within the Fizi gold panning sites greatly exceeded the WHO standards for total mercury levels in the hair of exposed individuals. Thus, the hair of individuals living in the Misisi gold-panning site had the highest average concentration of total mercury compared to the hair of individuals living in other gold-panning sites $\left(309.498 \pm 7.067 \mu \mathrm{g} \mathrm{g}^{-1}\right)$ followed successively by the hair of individuals living in the gold-panning sites of Nyangé 
(288.778 $\left.\pm 2.888 \mu \mathrm{g} . \mathrm{g}^{-1}\right) ; \quad$ Makungu $\left(261.131 \pm 3.657 \mu \mathrm{g} \cdot \mathrm{g}^{-1}\right)$; Lubichako I $\quad\left(218.924 \pm 1.386 \mu \mathrm{g} . \mathrm{g}^{-1}\right) ; \quad$ Lubichako II $\left(175.235 \pm 2.652 \mu \mathrm{g} . \mathrm{g}^{-1}\right)$ and Kuwa $\left(170.539 \pm 2.257 \mu \mathrm{g} \cdot \mathrm{g}^{-1}\right)$ with statistically similar mean total mercury concentrations in hair; and Ngalula $(145.897 \pm 1.915 \mu$ g.g- 1$)$ and Tulonge $\left(138,187 \pm 1,786 \mu \mathrm{g} \cdot \mathrm{g}^{-1}\right)$ with statistically similar mean total mercury concentrations in hair.

Total mercury concentrations in the hair of subjects living in all study sites varied significantly from one investigation campaign to the next $(\mathrm{P}$-value $=0.001)$ while experiencing slight increases from Campaign 1 (August 2016) to Campaign 4 (December 2017). In fact, Campaign 4 (December 2017), Campaign 3 (August 2017) and Campaign 2 (December 2016) had the highest levels of total mercury in hair, respectively of the order of $204.979 \pm 3.729 \mu \mathrm{g} . \mathrm{g}^{-1}$; $197.166 \pm 2.667 \mu \mathrm{g} . \mathrm{g}^{-1}$ and $195.606 \pm 2.470 \mu \mathrm{g} . \mathrm{g}^{-1}$ for which the mean values of the said levels are statistically identical. On the other hand, it can be observed that Campaign 1 (August 2016) presented total mercury levels in hair equivalent to $161.668 \pm 1.631 \mu \mathrm{g} . \mathrm{g}^{-1}$ which are lower than those of the three aforementioned Campaigns. These results are in clear agreement with those of other researchers who show that the levels of total mercury in the hair of individuals living outside gold mining sites in the Brazilian Amazon and the Kédougou region of eastern Senegal were significantly lower and in compliance with health standards than those of individuals living in the above gold mining sites whose hair total mercury levels greatly exceeded the health standards for total mercury levels in hair in exposed individuals. In addition, these researchers also reported that total mercury levels in hair varied very significantly from one site to another and significantly from one study campaign to another $[6,18]$.

\subsection{Total Mercury Content in Urine According to the Sites and Campaigns Studied}

The results in relation to total mercury concentrations in urine according to the sites and campaigns studied are highlighted in Table 3.

Table 3. Concentrations of total mercury (THg) in urine according to the sites and Campaigns studied.

\begin{tabular}{llcc}
\hline Sites / Campaigns and Parameter & Etó & Kacumvi & Kimbi \\
\hline THg $\left(\boldsymbol{\mu g} . \mathbf{L}^{-1}\right)$ & P-value for the Campaigns: $\mathbf{0 . 0 0 5}$ & \\
\hline Campaign 1 & $23.753 \pm 1.000$ & $26.369 \pm 1.874$ & $49.986 \pm 1.123$ \\
Campaign 2 & $30.226 \pm 1.114$ & $38.478 \pm 2.015$ & $29.485 \pm 1.175$ \\
Campaign 3 & $33.367 \pm 1.220$ & $44.672 \pm 2.120$ & $40.407 \pm 1.214$ \\
Campaign 4 & $36.770 \pm 1.229$ & $49.062 \pm 2.126$ & $38.511 \pm 1.236$ \\
Mean & $31.029 \pm 1.141 \mathrm{cde}$ & $39.645 \pm 2.034 c$ & $39.597 \pm 1.187 \mathrm{~cd}$ \\
\hline
\end{tabular}

Table 3. Continued.

\begin{tabular}{|c|c|c|c|c|c|c|}
\hline Sites / Campaigns and Parameter & Kuwa & Lubichako & Makungu & Mandje & Misisi & Mean \\
\hline THg $\left(\mu \mathrm{g} . \mathrm{L}^{-1}\right)$ & \multicolumn{6}{|c|}{ P-value for the Rivers: 0.000} \\
\hline Campaign 1 & $28.637 \pm 4.218$ & $74.753 \pm 1.921$ & $17.760 \pm 0.832$ & $61.511 \pm 1.963$ & $15.959 \pm 0.639$ & $33.420 \pm 1.509 b$ \\
\hline Campaign 2 & $80.350 \pm 4.259$ & $53.697 \pm 1.936$ & $22.942 \pm 1.000$ & $64.838 \pm 2.250$ & $17.177 \pm 0.971$ & $37.823 \pm 1.637 \mathrm{ab}$ \\
\hline Campaign 3 & $82.391 \pm 4.350$ & $57.860 \pm 2.211$ & $27.745 \pm 1.011$ & $65.136 \pm 2.260$ & $23.081 \pm 0.982$ & $42.034 \pm 1.709 \mathrm{a}$ \\
\hline Campaign 4 & $87.961 \pm 4.357$ & $70.009 \pm 2.216$ & $34.059 \pm 1.025$ & $69.295 \pm 2.267$ & $27.330 \pm 0.936$ & $46.402 \pm 1.712 \mathrm{aff}$ \\
\hline Mean & $69.835 \pm 4.296 a$ & $64.080 \pm 2.071 \mathrm{~b}$ & $25.626 \pm 0.967 \mathrm{ef}$ & $65.195 \pm 2.185 b$ & $20.887 \pm 0.882 f$ & $39.920 \pm 1.642$ \\
\hline
\end{tabular}

Averages with the same letters on the line or column are not statistically different at the significance level alpha =0.05; Campaign 1: August 2016; Campaign 2: December 2016; Campaign 3: August 2017; Campaign 4: December 2017; THg: Total mercury content.

Based on the results presented in Table 3, it appears that the mean values of total mercury concentrations in the urine of all people living in Lulimba (non-mining site or reference site) and in the gold panning areas of the Fizi territory (Kuwa, Misisi, Lubichako I, Ngalula, Lubichako II, Nyangé, Tulonge and Makungu) were of the order of $39.920 \pm 1.642$ $\mu \mathrm{g} . \mathrm{L}^{-1}$. Indeed, these values for total mercury concentrations in the urine of the above-mentioned individuals varied highly significantly from one site to another (P-value $=0.000)$. Specifically, at the non-mining site of Lulimba (reference site), the urine of individuals showed average total mercury concentrations of the order of $3.384 \pm 0.011 \mu \mathrm{g} . \mathrm{L}^{-1}$, which are the lowest and conform to WHO standards, stipulating that acceptable thresholds for total mercury levels in urine are less than $5.01 \mu \mathrm{g} . \mathrm{L}^{-1}$ (or $<25 \mathrm{nmol} . \mathrm{L}^{-1}$ ) for unexposed subjects and of the order of $6.02 \mu \mathrm{g} . \mathrm{L}^{-1}$ (or $30 \mathrm{nmol} . \mathrm{L}^{-1}$ ) for exposed subjects. However, total mercury levels in the urine of subjects living in the above-mentioned Fizi artisanal gold mining sites far exceeded WHO standards for total mercury levels in urine in exposed persons.

Thus, the urine of individuals living in the Misisi gold panning site had the highest average concentration of total mercury compared to the urine of individuals living in other gold panning sites $\left(69.835 \pm 4.296 \mu \mathrm{g} . \mathrm{L}^{-1}\right)$, followed successively by the urine of individuals living in the Nyangé gold panning sites $\left(65.195 \pm 2.185 \mu \mathrm{g} . \mathrm{L}^{-1}\right)$ and Makungu $\left(64.080 \pm 2.071 \mu \mathrm{g} . \mathrm{L}^{-1}\right)$ whose mean values of total mercury levels in the urine of subjects living in the above-mentioned sites are statistically similar; Lubichako I $(39.645 \pm 2.034$ $\left.\mu \mathrm{g} . \mathrm{L}^{-1}\right) ; \quad$ Lubichako II $\quad\left(39.597 \pm 1.187 \mu \mathrm{g} . \mathrm{L}^{-1}\right) ; \quad$ Kuwa (31.029 $\left.\pm 1.141 \mu \mathrm{g} . \mathrm{L}^{-1}\right) ; \quad$ Ngalula $\left(25.626 \pm 0.967 \mu \mathrm{g} . \mathrm{L}^{-1}\right)$; Tulonge (20.887 $\left.\pm 0.882 \mu \mathrm{g} . \mathrm{L}^{-1}\right)$.

Total mercury concentrations in the urine of subjects living within all the sites studied varied significantly from one investigation Campaign to another $(\mathrm{P}$-value $=0.005)$ while undergoing minute increases from Campaign 1 (August 
2016) to Campaign 4 (December 2017).

Indeed, Campaign 4 (December 2017) presented the highest values of average total mercury concentrations in urine for all the above-mentioned study sites (46.402 \pm 1.712 $\mu \mathrm{g} . \mathrm{L}^{-1}$ ) followed in turn by Campaign 3 (August 2017) for which the average total mercury concentrations in urine are of the order of $42.034 \pm 1.709 \mu \mathrm{g} . \mathrm{L}^{-1}$; Campaign 2 (December 2016) (37.823 $\left.\pm 1.637 \mu \mathrm{g} . \mathrm{L}^{-1}\right)$; and finally Campaign 1 (August 2016) for which the average concentrations of total mercury in urine were of the order of $33.420 \pm 1.509 \mu \mathrm{g} . \mathrm{L}^{-1}$. These results are consistent with those of other researchers who reported that total mercury levels in the urine of subjects living outside gold mining sites in the Brazilian Amazon and Guizhou, China, were the lowest and were within health standards compared to individuals living in the above gold mining sites whose total mercury levels in their urine far exceeded the health standards for total mercury levels in urine for exposed subjects. In addition to this, these researchers also revealed that total mercury levels in urine varied significantly from one site to another and significantly from one study Campaign to another $[1,18]$.

\subsection{Total Mercury Content in Blood According to the Categories of Subjects Exposed to Mercury and Investigation Campaigns}

The results related to total mercury levels in blood according to the categories of subjects exposed to mercury and investigative campaigns are presented in Table 4.

Table 4. Total mercury levels in blood according to the categories of subjects exposed to mercury and investigative Campaigns.

\begin{tabular}{|c|c|c|c|c|c|}
\hline \multirow{2}{*}{$\begin{array}{l}\text { Types of biological } \\
\text { matrices studied } \\
\text { (blood) }\end{array}$} & \multicolumn{4}{|l|}{ Categories of Mercury Exposed Subjects } & \multirow[b]{2}{*}{ Mean } \\
\hline & $\begin{array}{l}\text { Individuals living near gold-mercury amalgam } \\
\text { burning sites and gold trading houses }\end{array}$ & Gold traders & Gold panners & $\begin{array}{l}\text { Villagers residing in the } \\
\text { gold panning sites }\end{array}$ & \\
\hline THg $\left(\mu g . L^{-1}\right)$ & P-value for the Campaigns: 0.001 & \multicolumn{3}{|c|}{ P-value for categories of subjects exposed to mercury: 0.000} & \\
\hline Campaign 1 & $146.651 \pm 2.563$ & $202.880 \pm 1.087$ & $167.565 \pm 1.000$ & $92.909 \pm 2.022$ & $152.501 \pm 1.668 \mathrm{c}$ \\
\hline Campaign 2 & $232.641 \pm 3.157$ & $214.554 \pm 2.127$ & $268.544 \pm 1.121$ & $6.349 \pm 2.154$ & $180.522 \pm 2.140 b$ \\
\hline Campaign 3 & $203.271 \pm 3.093$ & $230.128 \pm 2.090$ & $291.611 \pm 1.020$ & $2.909 \pm 2.130$ & $181.980 \pm 2.083 b$ \\
\hline Campaign 4 & $197.403 \pm 3.120$ & $269.444 \pm 2.120$ & $273.980 \pm 1.110$ & $33.747 \pm 2.142$ & $193.644 \pm 2.123 \mathrm{a}$ \\
\hline Mean & $194.992 \pm 2.983 b$ & $229.252 \pm 1.856 a$ & $250.425 \pm 1.063 a$ & $33.978 \pm 2.112 c$ & $177.162 \pm 2.004$ \\
\hline
\end{tabular}

Averages with the same letters on the line or column are not statistically different at the significance level alpha =0.05; Campaign 1: August 2016; Campaign 2: December 2016; Campaign 3: August 2017; Campaign 4: December 2017; THg: Total mercury content.

The results reported in Table 4 show that the average values of total mercury concentrations in the blood of all categories of individuals exposed to mercury in the gold panning areas of the territory of Fizi were of the order of $177.162 \pm 2.004 \mu \mathrm{g} . \mathrm{L}^{-1}$. These values far exceed WHO health standards, which stipulate that acceptable levels of total mercury in blood are $8 \mu \mathrm{g} . \mathrm{L}^{-1}$ for unexposed people and 15 $\mu \mathrm{g} . \mathrm{L}^{-1}$ for exposed subjects. However, these values for total blood mercury levels in these categories of subjects varied highly significantly between the categories of subjects ( $\mathrm{P}$ value $=0.000$ ). Thus, the bloods of gold panners showed the highest average total mercury concentrations compared to those of the bloods of other categories of individuals exposed to mercury $\left(250.425 \pm 1.063 \mu \mathrm{g} . \mathrm{L}^{-1}\right)$, followed in turn by the bloods of gold traders $\left(229.252 \pm 1.856 \mu \mathrm{g} . \mathrm{L}^{-1}\right)$ whose average values of total mercury concentrations in their blood are statistically similar to those of gold panners; individuals living near gold-mercury ( $\mathrm{Au}-\mathrm{Hg}$ ) amalgamation incineration sites and gold trading houses (194.992 $\left.\pm 2.983 \mu \mathrm{g} . \mathrm{L}^{-1}\right)$; villagers residing in gold panning sites $\left(33.978 \pm 2.112 \mu \mathrm{g} . \mathrm{L}^{-1}\right)$.

Similarly, the concentrations of total mercury in the blood of various categories of subjects exposed to mercury in the Fizi gold panning areas varied significantly from one investigation Campaign to another $\left(\mathrm{P}\right.$-value $\left.=0.001 \mu \mathrm{g} . \mathrm{L}^{-1}\right)$ while increasing significantly from Campaign 1 (August 2016) to Campaign 4 (December 2017). Indeed, Campaign 4 (December 2017) presented the highest values of average total mercury concentrations in blood for all the above-mentioned categories of mercury exposed persons $\left(193.644 \pm 2.123 \mu \mathrm{g} . \mathrm{L}^{-1}\right)$ followed respectively by Campaign 3 (August 2017) for which the average total mercury concentrations in blood were of the order of $181.980 \pm 2.083 \mu \mathrm{g} . \mathrm{L}^{-1}$ and Campaign 2 (December 2016) (180.522 $\left.\pm 2.140 \mu \mathrm{g} . \mathrm{L}^{-1}\right)$ for which the average concentrations of total mercury in the blood are statistically identical; finally Campaign 1 (August 2016) for which the average concentrations of total mercury in the blood were of the order of $152.501 \pm 1.668 \mu \mathrm{g} . \mathrm{L}^{-1}$. These results are consistent with those of other researchers, including the finding that total mercury levels in blood alternately vary very significantly according to the categories of subjects exposed to mercury and the investigative Campaigns. Furthermore, they show that the longer the duration of exposure to mercury, the higher the concentration of this toxic metal in the blood and that total mercury levels in the blood are very high in the blood of gold panners, followed successively by gold traders, individuals living near gold-mercury amalgamation $(\mathrm{Au}-\mathrm{Hg})$ incineration sites and gold trading houses, and finally villagers living in gold panning sites [19-21].

\subsection{Total Mercury Content in Hair According to Categories of Subjects Exposed to Mercury and Investigation Campaigns}

The results for total mercury concentrations in hair according to the categories of mercury-exposed subjects and investigative campaigns are presented in Table 5. 
Table 5. Total mercury concentrations in hair according to categories of subjects exposed to mercury and investigative Campaigns.

\begin{tabular}{|c|c|c|c|c|c|}
\hline \multirow{2}{*}{$\begin{array}{l}\text { Types of biological } \\
\text { matrices studied } \\
\text { (hair) }\end{array}$} & \multicolumn{4}{|l|}{ Categories of Mercury Exposed Subjects } & \multirow[b]{2}{*}{ Mean } \\
\hline & $\begin{array}{l}\text { Individuals living near gold-mercury amalgam } \\
\text { burning sites and gold trading houses }\end{array}$ & Gold traders & Gold panners & $\begin{array}{l}\text { Villagers residing in the } \\
\text { gold panning sites }\end{array}$ & \\
\hline THg $\left(\mu \mathrm{gg.g}{ }^{-1}\right)$ & P-value for the Campaigns: 0.000 & \multicolumn{3}{|c|}{ P-value for categories of subjects exposed to mercury: 0.000} & \\
\hline Campaign 1 & $40.695 \pm 2.554$ & $60.802 \pm 3.312$ & $44.933 \pm 3.230$ & $30.739 \pm 2.111$ & $44.292 \pm 2.802 \mathrm{c}$ \\
\hline Campaign 2 & $61.264 \pm 2.568$ & $75.741 \pm 3.320$ & $91.028 \pm 3.236$ & $1.281 \pm 2.125$ & $57.328 \pm 2.812 b$ \\
\hline Campaign 3 & $62.179 \pm 2.630$ & $82.954 \pm 3.329$ & $89.175 \pm 3.242$ & $9.182 \pm 2.132$ & $60.872 \pm 2.833 b$ \\
\hline Campaign 4 & $78.674 \pm 2.634$ & $89.896 \pm 3.336$ & $96.495 \pm 3.258$ & $1.590 \pm 2.142$ & $66.664 \pm 2.842 \mathrm{a}$ \\
\hline Mean & $60.703 \pm 2.596 b$ & $77.348 \pm 3.324 a$ & $80.408 \pm 3.242 a$ & $10.698 \pm 2.128 c$ & $57.289 \pm 2.822$ \\
\hline
\end{tabular}

Averages with the same letters on the line or column are not statistically different at the significance level alpha $=0.05$; Campaign 1: August 2016; Campaign 2: December 2016; Campaign 3: August 2017; Campaign 4: December 2017; THg: Total mercury content.

The results in Table 5 show that the average values of total mercury concentrations in the hair of the different categories of subjects exposed to mercury in the gold panning areas of the territory of Fizi were of the order of $57.289 \pm 2.822 \mu \mathrm{g} . \mathrm{g}^{-1}$.

These values pitifully exceed the World Health Organization (WHO) standards, which stipulate that the acceptable thresholds for total mercury levels in hair are of the order of $2 \mu \mathrm{g} \cdot \mathrm{g}^{-1}$ for unexposed persons and $1 \mu \mathrm{g} \cdot \mathrm{g}^{-1}$ for exposed persons.

Nevertheless, these values for total mercury concentrations in the hair of various categories of individuals exposed to mercury varied highly significantly between categories of individuals $(\mathrm{P}$-value $=0.000)$. Thus, the hair of gold panners showed the highest average concentrations of total mercury compared to the hair of other categories of individuals exposed to mercury in the gold panning areas of Fizi $(80.408 \pm 3.242$ $\left.\mu \mathrm{g} . \mathrm{g}^{-1}\right)$ followed successively by the hair of gold traders $\left(77.348 \pm 3.324 \mu \mathrm{g} . \mathrm{g} . \mathrm{g}^{-1}\right)$ whose average values of total mercury concentrations are statistically similar to those of the gold panners; individuals living near $\mathrm{Au}-\mathrm{Hg}$ amalgam incineration sites and gold trading houses $\left(60.703 \pm 2.596 \mu \mathrm{g} . \mathrm{g}^{-1}\right)$; villagers living in the gold panning sites $\left(10.698 \pm 2.128 \mu \mathrm{g} . \mathrm{g}^{-1}\right)$.

Total mercury concentrations in the hair of different categories of mercury-exposed subjects in the Fizi gold panning areas also varied highly significantly from one survey campaign to another $(\mathrm{P}$-value $=0.000)$ while undergoing notable increases from Campaign 1 (August 2016) to Campaign 4 (December 2017).

By the way, Campaign 4 (December 2017), presented the highest values of average total mercury concentrations in hair for all categories of individuals exposed to mercury $\left(66.664 \pm 2.842 \mu \mathrm{g} . \mathrm{g}^{-1}\right)$ followed respectively by Campaign 3 (August 2017) for which the average total mercury concentrations in hair were of the order of $60.872 \pm 2.833$ $\mu \mathrm{g} . \mathrm{g}^{-1}$ and Campaign 2 (December 2016) (57.328 \pm 2.812 $\left.\mu \mathrm{g} . \mathrm{g}^{-1}\right)$ for which the average concentrations of total mercury in hair are statistically equal; and finally Campaign 1 (August 2016) for which the average concentrations of total mercury in hair were of the order of $44.292 \pm 2.802 \mu \mathrm{g} . \mathrm{g}^{-1}$.

These results are consistent with those of other researchers, who have found that total mercury levels in hair vary very significantly depending on the categories of individuals exposed to mercury and the investigative Campaigns. Thus, they indicate that total mercury levels in hair increase as the duration of exposure to mercury increases and that total mercury concentrations in hair are very high in the hair of gold panners, followed successively by gold traders, individuals living near gold-mercury $(\mathrm{Au}-\mathrm{Hg})$ amalgamation incineration sites and gold trading houses, and finally villagers living in gold panning sites [22-24].

\subsection{Total Mercury Content in Urine According to Categories of Subjects Exposed to Mercury and Investigation Campaigns}

The results related to total mercury concentrations in urine according to the categories of subjects exposed to mercury and investigative Campaigns are presented in Table 6.

Table 6. Total mercury concentrations in urine according to categories of subjects exposed to mercury and investigative Campaigns.

\begin{tabular}{|c|c|c|c|c|c|}
\hline \multirow{2}{*}{$\begin{array}{l}\text { Types of biological } \\
\text { matrices studied } \\
\text { (urine) }\end{array}$} & \multicolumn{4}{|l|}{ Categories of Mercury Exposed Subjects } & \multirow[b]{2}{*}{ Mean } \\
\hline & $\begin{array}{l}\text { Individuals living near gold-mercury amalgam } \\
\text { burning sites and gold trading houses }\end{array}$ & Gold traders & Gold panners & $\begin{array}{l}\text { Villagers residing in } \\
\text { the gold panning sites }\end{array}$ & \\
\hline THg $\left(\mu \mathrm{g} . \mathrm{L}^{-1}\right)$ & P-value for the Campaigns: 0.005 & \multicolumn{3}{|c|}{ P-value for categories of subjects exposed to mercury: 0.000} & \\
\hline Campaign 1 & $14.652 \pm 2.124$ & $41.522 \pm 1.110$ & $47.988 \pm 2.000$ & $26.644 \pm 1.210$ & $32.702 \pm 1.611 \mathrm{~b}$ \\
\hline Campaign 2 & $35.919 \pm 2.960$ & $46.891 \pm 2.215$ & $66.445 \pm 2.120$ & $3.208 \pm 1.310$ & $38.116 \pm 2.151 \mathrm{ab}$ \\
\hline Campaign 3 & $39.724 \pm 3.124$ & $53.532 \pm 2.225$ & $63.005 \pm 2.223$ & $4.862 \pm 1.314$ & $40.281 \pm 2.222 \mathrm{a}$ \\
\hline Campaign 4 & $54.114 \pm 3.242$ & $54.489 \pm 2.312$ & $63.307 \pm 4.231$ & $4.691 \pm 1.326$ & $44.150 \pm 2.778 \mathrm{a}$ \\
\hline Mean & $36.102 \pm 2.862 c$ & $49.108 \pm 1.966 b$ & $60.186 \pm 2.644 a$ & $9.851 \pm 1.290 d$ & $38.812 \pm 2.191$ \\
\hline
\end{tabular}

Averages with the same letters on the line or column are not statistically different at the significance level alpha $=0.05$; Campaign 1: August 2016; Campaign 2: December 2016; Campaign 3: August 2017; Campaign 4: December 2017; THg: Total mercury content.

The results presented in Table 6 show that the average values of total mercury concentrations in the urine of different categories of subjects exposed to mercury at gold panning sites in the territory of Fizi were of the order of $38.812 \pm 2.191 \mu \mathrm{g} . \mathrm{L}^{-1}$. These values greatly exceed the WHO standards, which stipulate that the acceptable thresholds for 
total mercury levels in urine are less than $5.01 \mu \mathrm{g} . \mathrm{L}^{-1}$ (or $<25$ nmol. $\mathrm{L}^{-1}$ ) for unexposed subjects and $6.02 \mu \mathrm{g} . \mathrm{L}^{-1}$ (or 30 nmol. $\mathrm{L}^{-1}$ ) for exposed subjects. However, these values of total mercury concentrations in the urine of different categories of people exposed to mercury in the artisanal gold mining areas of the territory of Fizi varied highly significantly from one category to another $(\mathrm{P}$-value $=0.000)$. Specifically, the urine of gold panners showed the highest average concentrations of total mercury compared to the urine of other individuals exposed to mercury in the gold panning areas of Fizi $\left(60.186 \pm 2.644 \mu \mathrm{g} . \mathrm{L}^{-1}\right)$ followed successively by the urine of gold traders $\left(49.108 \pm 1.966 \mu \mathrm{g} . \mathrm{L}^{-}\right.$ $\left.{ }^{1}\right)$; individuals living near $\mathrm{Au}-\mathrm{Hg}$ amalgam incineration sites and gold trading houses $\left(36.102 \pm 2.862 \mu \mathrm{g} . \mathrm{L}^{-1}\right)$; villagers residing in gold panning sites $\left(9.851 \pm 1.290 \mu \mathrm{g} . \mathrm{L}^{-1}\right)$.

In addition, total mercury concentrations in the urine of various categories of subjects exposed to mercury varied significantly from one investigation Campaign to another $(\mathrm{P}$ value $=0.005)$ while undergoing significant increases from Campaign 1 (August 2016) to Campaign 4 (December 2017). Indeed, Campaign 4 (December 2017) presented the highest values of average total mercury concentrations in urine for all categories of the above-mentioned individuals (44.150 \pm 2.778 $\mu \mathrm{g} . \mathrm{L}^{-1}$ ) followed in turn by Campaign 3 (August 2017) $\left(40.281 \pm 2.222 \mu \mathrm{g} . \mathrm{L}^{-1}\right)$ whose average values of total mercury concentrations in urine are statistically similar to those of
Campaign 4; of Campaign 2 (December 2016) for which the average values of total mercury concentrations were equal to $38.116 \pm 2.151 \mu \mathrm{g} . \mathrm{L}^{-1}$; and finally of Campaign 1 (August 2016) for which the average concentrations of total mercury in urine were of the order of $32.702 \pm 1.611 \mu \mathrm{g} . \mathrm{L}^{-1}$. These results do not deviate from those of other researchers who show that total mercury levels in urine vary successively very significantly according to the categories of people exposed to mercury and the investigative campaigns. Furthermore, they indicate that total mercury concentrations in urine increase as the duration of exposure to mercury increases and that total mercury concentrations in urine are reported to be very high in the urine of gold miners, followed successively by those of gold traders, those of individuals living near gold-mercury ( $\mathrm{Au}-\mathrm{Hg}$ ) cremation sites and gold trading houses, and finally those of villagers residing in gold panning sites [6, 23, 24].

\subsection{Total Mercury Levels in Hair According to the Categories of Subjects Exposed to Mercury and the Gold Panning Sites Studied}

Results that are consistent with total mercury concentrations in hair according to the categories of subjects exposed to mercury and the gold panning sites studied are presented in Table 7.

Table 7. Total mercury concentrations in hair according to the categories of subjects exposed to mercury and the gold panning sites studied.

\begin{tabular}{|c|c|c|c|c|c|}
\hline Sites / Parameter and the category of subjects exposed to $\mathrm{Hg}$ & Kuwa & Lubichako I & Lubichako II & Misisi & Makungu \\
\hline \multicolumn{6}{|l|}{ THg in the hair $\left(\mu \mathrm{g} . \mathrm{g}^{-1}\right)$} \\
\hline & \multicolumn{5}{|c|}{ P-value for categories of subjects exposed to mercury: 0.000} \\
\hline $\mathrm{I}$ & $54.927 \pm 0.014$ & $66.995 \pm 0.750$ & $34.734 \pm 0.017$ & $95.710 \pm 0.850$ & $84.480 \pm 0.864$ \\
\hline II & $39.580 \pm 0.021$ & $53.404 \pm 0.754$ & $53.564 \pm 0.025$ & $110.459 \pm 0.856$ & $85.225 \pm 0.685$ \\
\hline III & $45.209 \pm 0.030$ & $43.189 \pm 0.760$ & $60.160 \pm 0.032$ & $100.861 \pm 0.875$ & $81.492 \pm 0.740$ \\
\hline IV & $4.362 \pm 0.035$ & $6.945 \pm 0.763$ & $2.712 \pm 0.038$ & $20.325 \pm 1.369$ & $10.326 \pm 0.745$ \\
\hline Mean & $36,020 \pm 0.025 e$ & $42.633 \pm 0.757 d$ & $37.792 \pm 0.028 e$ & $81.839 \pm 0.988 a$ & $65.381 \pm 0.758 c$ \\
\hline
\end{tabular}

Table 7. Continued

\begin{tabular}{|c|c|c|c|c|}
\hline Sites / Parameter and the category of subjects exposed to $\mathrm{Hg}$ & Ngalula & Nyangé & Tulonge & Mean \\
\hline \multicolumn{5}{|l|}{ THg in the hair $\left(\mu{\left.\mathrm{g} . \mathrm{g}^{-1}\right)}^{-1}\right.$} \\
\hline \multicolumn{5}{|c|}{ P-value for the sites: 0.000} \\
\hline I & $33.091 \pm 0.073$ & $73.235 \pm 1.635$ & $31.694 \pm 0.070$ & $59.358 \pm 0.534 \mathrm{c}$ \\
\hline II & $46.491 \pm 0.079$ & $88.527 \pm 1.872$ & $47.519 \pm 0.076$ & $65.596 \pm 0.546 b$ \\
\hline III & $55.354 \pm 0.085$ & $130.246 \pm 1.963$ & $56.945 \pm 0.080$ & $71.682 \pm 0.571 \mathrm{a}$ \\
\hline IV & $3.896 \pm 0.092$ & $15.986 \pm 2.230$ & $2.612 \pm 0.090$ & $8.396 \pm 0.670 \mathrm{~d}$ \\
\hline Mean & $34.708 \pm 0.082 f$ & $76.998 \pm 1.925 b$ & $34.692 \pm 0.079 f$ & $51.258 \pm 0.580$ \\
\hline
\end{tabular}

Averages with the same letters in the row or column are not statically different at the significance level alpha=0.05; I= Individuals living near Au- $\mathrm{Hg}$ amalgam incineration sites and gold trading houses; $\mathrm{II}=$ Gold traders; III = Gold panners; IV = Villagers living in gold panning sites; HgT = total mercury content; THg $=$ total mercury content

In view of the results shown in Table 7, it appears that the average values of total mercury concentrations in the hair of all categories of individuals exposed to mercury in the gold panning sites in the territory of Fizi were of the order of $51.258 \pm 0.580 \mu \mathrm{g} \cdot \mathrm{g}^{-1}$. These values greatly exceed the acceptable limit levels of $1 \mu \mathrm{g} \cdot \mathrm{g}^{-1}$ for exposed subjects. In addition, the values of total mercury levels in the hair of the said subjects varied in a highly significant manner from one category of subjects to another $(\mathrm{P}$-value $=0.000)$. Thus, for all gold panning sites, gold panners' hair had the highest average total mercury concentration relative to the average total mercury concentrations in hair of other categories of mercury-exposed subjects at artisanal gold mining sites $\left(71.682 \pm 0.571 \mu \mathrm{g} . \mathrm{g}^{-1}\right)$ followed alternately by the hair of gold traders $\left(65.596 \pm 0.546 \mu \mathrm{g} . \mathrm{g}^{-1}\right)$, hair of individuals living near $\mathrm{Au}-\mathrm{Hg}$ amalgam burning sites and gold trading houses 
$\left(59.358 \pm 0.534 \mu \mathrm{g} . \mathrm{g}^{-1}\right)$, hair of villagers residing in gold panning sites $\left(8.396 \pm 0.670 \mu \mathrm{g} \cdot \mathrm{g}^{-1}\right)$.

Similarly, the values of total mercury concentrations in the hair of subjects exposed to mercury at different gold panning sites in Fizi varied highly significantly from one gold panning site to another $(\mathrm{P}$-value $=0.000)$. In fact, the hair of people exposed to mercury at the Misisi gold-panning site had the highest average total mercury concentration compared to the hair of people living in other gold-panning sites $\left(81.839 \pm 0.988 \mu \mathrm{g} . \mathrm{g}^{-1}\right)$ followed successively by the hair of people living in the gold-panning sites in Nyangé $\left(76.998 \pm 1.925 \mu \mathrm{g} . \mathrm{g}^{-1}\right) ; \quad$ Makungu $\left(65.381 \pm 0.758 \mu \mathrm{g.g} \mathrm{g}^{-1}\right)$; Lubichako I $\left(42.633 \pm 0.757 \mu \mathrm{g} . \mathrm{g}^{-1}\right)$; then Lubichako II $\left(37.792 \pm 0.028 \mu \mathrm{g} . \mathrm{g}^{-1}\right)$ and Kuwa $\left(36.020 \pm 0.025 \mu \mathrm{g} . \mathrm{g}^{-1}\right)$ with statistically similar mean total mercury concentrations in hair; and Ngalula $\left(34.708 \pm 0.082 \mu \mathrm{g} . \mathrm{g}^{-1}\right)$ and Tulonge $\left(34.692 \pm 0.079 \mu \mathrm{g} . \mathrm{g}^{-1}\right)$ with statistically similar mean total mercury concentrations in hair.
These results are similar to those of other researchers who show that the levels of total mercury in the hair vary successively in a very significant way according to the categories of individuals exposed to mercury and the gold panning sites studied in that these concentrations would be very high in the hair of gold panners, followed respectively by those of gold traders, those of individuals living near gold-mercury ( $\mathrm{Au}-\mathrm{Hg}$ ) incineration sites and gold trading houses, and those of villagers living in gold panning sites [22-24].

\subsection{Total Mercury Levels in Blood According to the Categories of Subjects Exposed to Mercury and the Gold Panning Sites Studied}

The results for total mercury levels in blood according to the categories of subjects exposed to mercury and the gold panning sites studied are presented in Table 8.

Table 8. Concentrations of total mercury in blood according to the categories of subjects exposed to mercury and the gold panning sites studied.

\begin{tabular}{|c|c|c|c|c|c|}
\hline $\begin{array}{l}\text { Sites / Parameter and the category of subjects } \\
\text { exposed to } \mathrm{Hg}\end{array}$ & Kuwa & Lubichako I & Lubichako II & Misisi & Makungu \\
\hline \multicolumn{6}{|l|}{ THg in the blood $\left(\mu \mathrm{g} . \mathrm{L}^{-1}\right)$} \\
\hline \multicolumn{6}{|c|}{$\begin{array}{c}\text { P-value for categories of subjects exposed to mercury: } 0.000 \\
\end{array}$} \\
\hline I & $150.377 \pm 0.579$ & $179.136 \pm 0.967$ & $213.575 \pm 0.690$ & $297.613 \pm 1.247$ & $162.655 \pm 1.647$ \\
\hline II & $174.293 \pm 0.678$ & $213.879 \pm 1.523$ & $144.885 \pm 1.007$ & $299.079 \pm 1.254$ & $262.141 \pm 1.650$ \\
\hline III & $175.637 \pm 0.798$ & $211.439 \pm 2.369$ & $143.871 \pm 1.031$ & $389.025 \pm 1.260$ & $257.965 \pm 1.720$ \\
\hline IV & $20.015 \pm 0.421$ & $20.254 \pm 0.360$ & $26,356 \pm 0.237$ & $30.242 \pm 1.267$ & $28.321 \pm 1.725$ \\
\hline Mean & $130.081 \pm 0.619 e$ & $156.177 \pm 1.305 \mathrm{~d}$ & $132.172 \pm 0.741 e$ & $253.990 \pm 1.257 a$ & $177.771 \pm 1.686 c$ \\
\hline
\end{tabular}

Table 8. Continued.

\begin{tabular}{|c|c|c|c|c|}
\hline Sites / Parameter and the category of subjects exposed to $\mathrm{Hg}$ & Ngalula & Nyangé & Tulonge & Mean \\
\hline \multicolumn{5}{|l|}{ THg in the blood $\left(\mu \mathrm{g} . \mathrm{L}^{-1}\right)$} \\
\hline & \multicolumn{4}{|c|}{ P-value for the sites: 0.000} \\
\hline I & $146.900 \pm 0.124$ & $223.414 \pm 1.011$ & $176.995 \pm 0.127$ & $193.833 \pm 0.799 \mathrm{c}$ \\
\hline II & $158.772 \pm 0.130$ & $274.645 \pm 1.015$ & $130.851 \pm 0.214$ & $207.318 \pm 0.934 b$ \\
\hline III & $185.365 \pm 0.147$ & $309.111 \pm 1.030$ & $151.701 \pm 0.263$ & $228.014 \pm 1.077 \mathrm{a}$ \\
\hline IV & $19.875 \pm 0.062$ & $43.270 \pm 1.036$ & $24.654 \pm 0.975$ & $26.623 \pm 0.760 \mathrm{~d}$ \\
\hline Mean & $127.728 \pm 0.116 f$ & $212.610 \pm 1.023 b$ & $121.050 \pm 0.395 \mathrm{~g}$ & $163.947 \pm 0.893$ \\
\hline
\end{tabular}

Averages with the same letters in the row or column are not statically different at the significance level alpha $=0.05$; $\mathrm{I}=$ Individuals living near Au- $\mathrm{Hg}$ amalgam incineration sites and gold trading houses; II = Gold traders; III = Gold panners; IV = Villagers living in gold panning sites; $\mathrm{HgT}=$ total mercury content; $\mathrm{THg}$ $=$ total mercury content.

In view of the results highlighted in Table 8 , it appears that the average values of total mercury concentrations in the blood of all categories of people exposed to mercury in the gold panning sites in the territory of Fizi were equal to $163.947 \pm 0.893 \mu \mathrm{g} . \mathrm{L}^{-1}$. These values greatly exceed the acceptable limit levels of $15 \mu \mathrm{g} . \mathrm{L}^{-1}$ for exposed individuals. However, the values of total mercury levels in the blood of the subjects in question varied highly significantly from one category of subjects to another $(\mathrm{P}$-value $=0.000)$. Thus, for all gold panning sites, gold panners' bloods had the highest average total mercury concentration relative to the average total mercury concentrations in the bloods of other categories of mercury-exposed subjects at the gold panning sites $\left(228.014 \pm 1.077 \mu \mathrm{g} . \mathrm{L}^{-1}\right)$ followed in turn by the bloods of gold traders $\left(207.318 \pm 0.934 \mu \mathrm{g} . \mathrm{L}^{-1}\right)$, the bloods of individuals living near $\mathrm{Au}-\mathrm{Hg}$ amalgamation incinerator sites and gold trading houses $\left(193.833 \pm 0.799 \mu \mathrm{g} . \mathrm{L}^{-1}\right)$, and the bloods of villagers residing in gold panning sites $\left(26.623 \pm 0.760 \mu \mathrm{g} . \mathrm{L}^{-1}\right)$.

Moreover, the values of total mercury concentrations in the blood of people exposed to mercury at different gold panning sites in Fizi varied highly significantly from one gold panning site to another (P-value $=0.000)$.by the way, the blood of people exposed to mercury at the Misisi gold panning site had the highest average concentration of total mercury compared to the blood of people living at other gold panning sites $\left(253.990 \pm 01.257 \mu\right.$ g. $\left.\mathrm{L}^{-1}\right)$ followed respectively by the bloods of people living in the gold panning sites of Nyangé (212.610 $\left.\pm 1.023 \mu \mathrm{g} . \mathrm{L}^{-1}\right)$; Makungu $\left(177.771 \pm 1.686 \mu \mathrm{g} . \mathrm{L}^{-1}\right)$; Lubichako I $\left(156.177 \pm 1.305 \mu \mathrm{g} . \mathrm{L}^{-1}\right)$; then Lubichako II $\left(132.172 \pm 0.741 \quad \mu\right.$ g. $\left.L^{-1}\right)$ and Kuwa $\left(130.081 \pm 0.619 \mu \mathrm{g} . \mathrm{L}^{-1}\right)$ with statistically similar mean total blood mercury concentrations; Ngalula (127.728 $\left.\pm 0.116 \mu \mathrm{g} . \mathrm{L}^{-1}\right)$ and Tulonge (121.050 $\left.\pm 0.395 \mu \mathrm{g} . \mathrm{L}^{-1}\right)$.

These results are similar to those of other researchers who show that the levels of total mercury in the blood vary very 
significantly depending on the categories of subjects exposed to mercury and the gold panning sites studied, to the point that the above-mentioned levels would be very high in the blood of gold panners, followed successively by those of gold traders, those of individuals living near gold-mercury ( $\mathrm{Au}-\mathrm{Hg}$ ) cremation sites and gold trading houses, and finally those of villagers living in gold panning sites [18-21].

\subsection{Total Mercury Levels in Urine According to the Categories of Subjects Exposed to Mercury and the Gold Panning Sites Studied}

Results for total mercury levels in urine according to the categories of subjects exposed to mercury and the gold panning sites studied are shown in Table 9.

Table 9. Total mercury concentrations in urine according to the categories of subjects exposed to mercury and the gold panning sites studied.

\begin{tabular}{|c|c|c|c|c|c|}
\hline $\begin{array}{l}\text { Sites/ Parameter and the category of } \\
\text { subjects exposed to } \mathrm{Hg}\end{array}$ & Kuwa & Lubichako I & Lubichako II & Misisi & Makungu \\
\hline \multicolumn{6}{|l|}{ THg in the urine $\left(\mu \mathrm{g} . \mathrm{L}^{-1}\right)$} \\
\hline & \multicolumn{5}{|c|}{ P-value for categories of subjects exposed to mercury: 0.000} \\
\hline I & $33.529 \pm 0.072$ & $17.682 \pm 0.238$ & $26.213 \pm 0.025$ & $44.009 \pm 0.631$ & $61.369 \pm 0.310$ \\
\hline II & $27.452 \pm 0.048$ & $32.699 \pm 0.367$ & $44.636 \pm 0.032$ & $58.539 \pm 0.700$ & $68.671 \pm 0.325$ \\
\hline III & $24.699 \pm 0.056$ & $66.730 \pm 0.430$ & $42.273 \pm 0.020$ & $99.673 \pm 0.711$ & $57.367 \pm 0.623$ \\
\hline IV & $16.574 \pm 0.087$ & $14.012 \pm 0.452$ & $10.269 \pm 0.010$ & $67.223 \pm 0.721$ & $16.362 \pm 0.264$ \\
\hline Mean & $25.564 \pm 0.066 f$ & $32.781 \pm 0.372 d$ & $30.848 \pm 0.022 e$ & $67.361 \pm 0.691 a$ & $50.942 \pm 0.381 c$ \\
\hline
\end{tabular}

Table 9. Continued.

\begin{tabular}{|c|c|c|c|c|}
\hline $\begin{array}{l}\text { Sites/ Parameter and the category of } \\
\text { subjects exposed to } \mathrm{Hg}\end{array}$ & Ngalula & Nyangé & Tulonge & Mean \\
\hline \multicolumn{5}{|l|}{ THg in the urine $\left(\mu \mathrm{g} . \mathrm{L}^{-1}\right)$} \\
\hline \multicolumn{5}{|c|}{ P-value for the sites: 0.000} \\
\hline $\mathrm{I}$ & $22.122 \pm 0.036$ & $62.170 \pm 0.562$ & $29.434 \pm 0.127$ & $37.066 \pm 0.250 \mathrm{c}$ \\
\hline II & $31.731 \pm 0.030$ & $69.374 \pm 0.870$ & $19.792 \pm 0.217$ & $44.112 \pm 0.324 b$ \\
\hline III & $34.139 \pm 0.024$ & $77.901 \pm 0.980$ & $28.753 \pm 0.326$ & $53.942 \pm 0.396 \mathrm{a}$ \\
\hline IV & $11.236 \pm 0.014$ & $19.625 \pm 0.873$ & $15.632 \pm 0.018$ & $21.367 \pm 0.305 \mathrm{~d}$ \\
\hline
\end{tabular}

Averages with the same letters in the row or column are not statically different at the significance level alpha=0.05; $\mathrm{I}=\mathrm{Individuals}$ living near Au-Hg amalgam incineration sites and gold trading houses; II= Gold traders; III = Gold panners; IV = Villagers living in gold panning sites; HgT = total mercury content; THg $=$ total mercury content.

The results presented in Table 9 show that the mean values of total mercury concentrations in the urine of all categories of people exposed to mercury at gold panning sites in the Fizi territory were equivalent to $39.122 \pm 0.319 \mu \mathrm{g} . \mathrm{L}^{-1}$. These values are well above the acceptable limit levels of 6.020 $\mu \mathrm{g} . \mathrm{L}^{-1}$ (or $30 \mathrm{nmol} . \mathrm{L}^{-1}$ ) for the subjects. Nevertheless, the values of total mercury levels in the urine of the individuals in question varied highly significantly from one category of subjects to another $(\mathrm{P}$-value $=0.000)$. For all gold panning sites, the urine of gold panners had the highest average total mercury concentration relative to the average total mercury concentrations in the urine of other categories of mercuryexposed individuals at the gold panning sites (53.942 \pm 0.396 $\mu \mathrm{g} . \mathrm{L}^{-1}$ ) followed respectively by the urine of gold traders $\left(44.112 \pm 0.324 \mu \mathrm{g} . \mathrm{L}^{-1}\right)$, urine of individuals living near Au$\mathrm{Hg}$ amalgam incinerator sites and gold trading houses (37.066 $\left.\pm 0.250 \mu \mathrm{g} . \mathrm{L}^{-1}\right)$, urine of villagers residing in gold panning sites $\left(21.367 \pm 0.305 \mu \mathrm{g} . \mathrm{L}^{-1}\right)$. The values of total mercury concentrations in the urine of subjects exposed to mercury at different gold panning sites in Fizi also varied highly significantly from one gold panning site to another (Pvalue $=0.000)$. Thus, the urine of subjects exposed to mercury at the Misisi gold panning site had the highest average total mercury concentration compared to the urine of subjects living in other gold panning sites $\left(67.361 \pm 0.691 \mu \mathrm{g} . \mathrm{L}^{-}\right.$ ${ }^{1}$ ) followed in turn by the urine of people living in the gold panning sites of Nyangé (57.268 $\left.\pm 0.821 \mu \mathrm{g} . \mathrm{L}^{-1}\right)$; Makungu
(50.942 $\left.\pm 0.381 \mu \mathrm{g} . \mathrm{L}^{-1}\right)$; Lubichako I $\left(32.781 \pm 0.372 \mu \mathrm{g} . \mathrm{L}^{-1}\right)$; Lubichako II $\left(30.848 \pm 0.022 \mu \mathrm{g} . \mathrm{L}^{-1}\right)$; Kuwa $(25.564 \pm 0.066$ $\left.\mu \mathrm{g} . \mathrm{L}^{-1}\right) ; \quad$ Ngalula $\quad\left(24.807 \pm 0.026 \quad \mu \mathrm{g} . \mathrm{L}^{-1}\right) ; \quad$ Tulonge $\left(23.403 \pm 0.172 \mu \mathrm{g} . \mathrm{L}^{-1}\right)$. These results are similar to those of other researchers who state that total mercury levels in urine vary very significantly depending on the categories of people exposed to mercury and the gold panning sites studied, so that the above-mentioned levels would be very high in the urine of gold panners, followed successively by those of gold traders, those of individuals living near gold-mercury (Au-Hg) cremation sites and gold trading houses, and finally those of villagers living in gold panning sites [23, 24].

\section{Conclusion}

Only people residing at the reference site or non-mining site (Lulimba) had the lowest average total mercury concentrations that met WHO standards for all biological matrices studied (blood, hair and urine). Gold panners had the highest total mercury concentrations in the said biological matrices, followed respectively by gold traders, individuals living near gold-mercury ( $\mathrm{Au}-\mathrm{Hg}$ ) amalgamation incineration sites and gold trading houses, and villagers residing in gold panning sites.

In view of these amply elevated mercury concentrations in the blood, urine and hair of the subjects who participated in this study, it is important to consider adequate solutions 
capable of protecting people against mercury toxicity. In order to do so, particular attention would be focused on the scrupulous application of safety standards in relation to the handling of mercury in general and other toxic products in particular, on the conduct to be followed during the incineration of gold-mercury amalgam, etc.

\section{Acknowledgements}

We sincerely thank the gold miners, the gold traders and the inhabitants of the gold mining sites in the Fizi territory; $\mathrm{Mr}$ Nakalonge André and Mr Mwimangire Cephas for lending us a strong hand during the completion of this research.

\section{References}

[1] Buyun, D., Ping, L., Xinbin, F., Guangle, Q., Z. Jun and M. Laurence., Mercury Exposure in Children of the Wanshan Mercury Mining Area, Guizhou, China. International Journal of Environmental Research and Public Health 2016. 13: p. $1107-1122$.

[2] Tomiyasu, T., Kono, Y., Kodamatani, H., N. Hidayati and J. S. Rahajoe, The distribution of mercury around the small-scale gold mining area along the Cikaniki river, Bogor, Indonesia. Environmental Research 2013. 125: p. 12-19.

[3] P. Van Straaten, Mercury contamination associated with smallscale gold mining in Tanzania and Zimbabwe. The Science of The Total Environment 2000. 259: p. 105-113.

[4] PNUE, Utilisation du mercure dans l'extraction minière artisanale et à petite échelle de l'or, Genève, 2008.

[5] R. T. Laurie, Impacts des activités minières sur les ressources en eau en Afrique de l'Ouest: Cas des mines aurifères, AgroParisTech-ENGREF-CCRE-CEDEAO, Burkina Faso, 2012.

[6] B. Niane, Impacts environnementaux liés à l'utilisation du mercure lors de l'exploitation artisanale de l'or dans la région de Kédougou (Sénégal oriental). Thèse de doctorat en Sciences de la Terre, Université de Genève, Genève, 2014.

[7] M. A. H, Détermination $d u$ mercure: méthode par spectrophotométrie d'absorption atomique, formation de vapeur. Centre d'expertise en analyse environnementale du Québec, 2006.

[8] L. J. Casarett and J. Doull, Toxicology. Basic science of poisons 2008. 23: p. 931-979.

[9] S. A. Gilbert, Small Dose of Toxicology. Toxipedia 2010.1 (3): p. 23-34.

[10] WHO, Report on indicators to evaluate and track the health impacts of mercury and identify vulnerabale populations., Geneva, Switzerland, 2010.
[11] W. N. Munyaas, Territoire de Fizi-Kalembelembe, défis et développement. Ed. Persée, Paris, 2016.

[12] M. Marc et F. Mario, Biostatistique pour les sciences de la vie et de la santé. Ed Pearson, Paris, 2012.

[13] W. Cochran, Sampling techniques. Ed John Wiley \& Sons. New York, 1977.

[14] Schach, V., Jahanbakht, S., Livardjani, F., Reiss, J., A. Jaeger and Y. Haïkel. Surveillance médicale des sujets exposés professionnellement au mercure. Archive des maladies professionnelles 2010. 5: p. 59-68.

[15] L. Laurence, La préparation des matrices biologiques pour l'analyse des métaux. Annales de ToxicologieAnalytique2010. 22 (2): p. 81-88.

[16] A. Hirokatsuand N. Akira, Human Exposure to Mercury and the Accumulation of Methylmercury that is Associated with Gold Mining in the Amazon Basin, Brazil. Journal of Health Science 2006. 46 (5): p. 323-328.

[17] Gun, P., Young, S., J. Man and S. Joon, The associations between blood mercury levels and shark meat intake among workers in Gyeongsangbuk-do. Occupational and Environmental Medicine 2006.2: p. 29-39.

[18] Vieira, S., Almeida, R., Holanda I., Mussy, M., Galvao R., Crispin, P., J. Dorea, and W. Bastos, Total and methyl-mercury in hair and milk of mothers living in the city of Porto Velho and in villages along the Rio Madeira, Amazon, Brazil. International Journal of Hygiene and Environmental Health 2013.216 (6): p. 682-689.

[19] Brodkin, E., Copes, R., Mattman, A., Kennedy, J., R. Kling and A. Yassi, Lead and mercury exposures: interpretation and action. CMAJ2017. 176 (1): p. 59-63.

[20] N. Kim and B. Lee, Blood total mercury and fish consumption in the Korean general population in Khanes III. Sci Total Environ 2010. 408 (20): p. 4841-7.

[21] Lye, E., Legrand, M., J. Clarke and A. Probert, Blood total mercury concentrations in the Canadian population: Canadian health measures survey cycle 1, 2007-2009. Can J Public Health 2013.104 (3): p. 246-251.

[22] L. Kern, Interpreting Hair Mercury Levels in Individual Patients. Annals of Clinical \& Laboratory Science2009. 36 (3): p. 249-261.

[23] Guixia, C., Xiaoxin, C., Chonghuai, Y., W. Xingdong and Z. Guozhang. Surveying Mercury Levels in Hair, Blood and Urine of under 7-Year Old Children from a Coastal City in China. Int. J. Environ. Res. Public Health. 2014. 11: p. 1202912041.

[24] Pirrone, N., Cinnirella, S., Feng, X., Finkelman, R., Friedli, H., J. Leaner and R. Mason, Global mercury emissions to the atmosphere from anthropogenic and natural sources. Atmos. Chem. Phys 2010. 10: p. 5951-5964. 